\title{
The Impact of Legal Status on Different Schooling Aspects of Adolescents in Germany
}

\author{
CHRISTOPH HOMUTH, JÖRG WELKER, GISELA WILL, AND JUTTA VON MAURICE
}

\section{Abstract}

During the so-called refugee crisis of 2015, approximately 300,000 underage asylum seekers came to Germany. We examine whether their legal status and their subjective perception of their status are equally important for their educational integration. On the basis of rational choice theory, we hypothesize that refugees' legal status should affect their educational outcomes. Our study finds no differences among students with different legal statuses in school placement. However, students who perceive their status as insecure report significantly worse GPA than students who feel rather secure. Concerning the objective legal status, we do find that students with an insecure legal status report better grades than those with a granted refugee status. These contrary results show the importance of additionally considering status perception in understanding and explaining educational outcomes of immigrants in further research. Educators should be aware of the potential divergence between objective and subjective status and their corresponding effects on educational trajectories.

\section{Résumé}

Pendant la soi-disant "crise des réfugiés» de 2015, approximativement 300 ooo demandeurs d'asile d'âge mineur sont arrivés en Allemagne. Nous examinons si leur statut légal et la perception subjective qu'ils ont de leur statut ont une importance égale en ce qui concerne leur intégration éducative. Nous appuyant sur la théorie du choix rationnel, nous émettons des hypothèses sur la manière dont le statut légal des réfugiés affecte leurs résultats scolaires. Notre étude ne révèle aucune divergence entre les étudiants de statuts légaux différents dans le placement scolaire. Cependant, les étudiants qui perçoivent leur statut comme précaire rapportent des moyennes significativement plus basses que ceux qui ont un plus grand sentiment de sécurité. En ce qui concerne le statut légal objectif, nous constatons que les étudiants au statut précaire rapportent de meilleures notes que ceux qui ont reçu le statut de réfugié. Ces résultats contradictoires montrent qu'il est important de tenir compte de la manière dont les immigrants perçoivent leur statut afin de comprendre et d'expliquer leurs résultats scolaires lors de recherches ultérieures. Les éducateurs devraient être conscients des potentielles divergences entre le statut objectif (c) C. Homuth, j. Welker, G. Will, and J. von Maurice, 2020. This open-access work is licensed under a Creative Commons Attribution-NonCommercial 4.o International Licence, which permits use, reproduction, and distribution in any medium for non-commercial purposes, provided the original authorship is credited and the original publication in Refuge: Canada's Journal on Refugees is cited.
Cette œuvre en libre accès fait l'objet d'une licence Creative Commons Attribution-NonCommercial 4.0 International License, laquelle autorise l'utilisation, la reproduction et la distribution de l'œuvre sur tout support à des fins non commerciales, pourvu que l'auteur ou les auteurs originaux soient mentionnés et que la publication originale dans Refuge: revue canadienne sur les réfugiés soit citée. 
et le statut subjectif ainsi que leurs effets sur les trajectoires éducatives.

\section{Introduction}

ccording to the United Nations High Commissioner for Refugees (UNHCR), by the end of 2018, 70.8 million 1 people worldwide were forcibly displaced (UNHCR, 2019). In 2015, approximately $86 \%$ of all refugees registered worldwide were in countries in the Global South (Oltmer, 2016). However, the number of refugees applying for asylum in the Global North is also increasing. From 2013 to 2017, approximately 4.3 million refugees came to Europe, including approximately 1.8 million who came to Germany (BAMF, 2018). Germany ranked among the top five refugee-receiving countries worldwide in 2018 and second in Europe after Turkey (UNHCR, 2019). Therefore, Germany offers a particularly interesting case study on the integration of refugees.

Approximately one-third of the refugees who came to Germany were minors who fled with or without their parents from war, natural disasters, political persecution, or other reasons. For these underage refugees, the educational system plays a central role in integrating them into German society, as education is the central precondition for social and economic opportunities in later life for all children and adolescents (OECD, 2020) and especially for refugees (Nationaler Aktionsplan Integration, 2012), regardless of the country in which they will live.

Most school-aged refugees receive some form of formal education in Germany. ${ }^{1}$ In most countries, certain rights are limited to their citizens or persons who are treated as nationals, most prominent among these being the right to work, the right to vote, or the right to receive certain welfare benefits-a situation that is discussed in the literature as civic stratification (see, e.g., Morris, 2003; Söhn, 2014). Access to certain educational offerings may also depend on legal status. The rights that refugees have in the host society are tied to legal status in particular. Refugees who do not receive a secure legal status are limited in some aspects. For example, their access to the labour market or entitlement to family reunification may be restricted. Furthermore, refugees must cope with the possibility of deportation. It can be expected that this uncertainty will shape the decisions they make, including educational decisions, e.g., how likely they are to invest in language acquisition or longer educational paths with uncertain ends and potentially country-specific educational degrees.
The aim of this contribution is to analyze, for the first time, whether and how legal status determines schooling aspects of refugees in Germany. Furthermore, our study extends the literature and considers the objective legal status and the subjectively perceived insecurity of the refugees' legal status in our models. We believe that this perspective yields insights into how individuals perceive their legal status and, subsequently, assess their prospects to remain in the host country. Perceptions can have important implications for individuals' decisions on whether to invest in education in the host country. A better understanding of the connection between refugees' legal status and educational outcomes is of practical importance, not only for Germany but also for other countries. It helps policy-makers to set the right legal frameworks to facilitate rapid integration into their host societies. It is further relevant for teachers and practitioners who want to support refugee students daily in schools to develop their educational potentials on the one hand, and parents on the other hand. This extended view facilitates a better understanding of the situation of refugee adolescents and contributes to solutions that concentrate on not only normal learning strategies but also strategies to cope with precarious situations.

We argue that there should be virtually no impact of legal status on structural educational chances if all refugees have access to the regular German school system. However, we do posit that the refugees' subjectively expected chances of staying in Germany affect their educational decision-making and investment in their education.

Our study relies on a unique dataset from the panel study Refugees in the German Educational System (ReGES). The focus of this article is on the educational situation of adolescents at the end of compulsory schooling in Germany, i.e., the end of secondary school as the basis for their educational trajectories in the coming years.

\section{Prior Evidence of the Effect of Legal Status on Education}

There have been very few studies on the effect of legal status on education.

In the United States, children of refugees were found to have the lowest educational outcomes of all groups under study, but this finding was explained mainly by differences in their parents' educational attainment and not due to their legal status (Lee, 2018).

Two studies on educational disadvantages of undocumented immigrants in the United States have shown that

1. Initial results from the IAB-BAMF-SOEP survey of refugees, which also include refugees in reception centres, show that only $8 \%$ of 11 - to 14 -year-olds and $13 \%$ of 15 - to 16 -year-olds among the refugees had not (yet) attended school at the time of the interview (see de Paiva Lareiro, 2019). 
undocumented adolescents were less likely to graduate from high school as well as to enrol in college (Greenman \& Hall, 2013; Patler, 2018). Neither study fully explains which mechanisms cause the educational disadvantages of undocumented migrants to remain but the findings point toward unfavourable legal conditions leading to these disadvantages.

For Germany, there is evidence that adolescents with an Aussiedler ${ }^{2}$ status are more likely than other status groups to achieve an intermediate or higher school-leaving certificate versus a lower school-leaving certificate, and therefore they have better chances on the vocational training market than other immigrant groups. The disparity becomes even more substantial when comparing Aussiedler adolescents to other migrants who came to Germany as civil war refugees from the former Yugoslavia. The author concludes that differences in legal conditions, as well as migrant selectivity, can explain differences in educational success (Söhn, 2011).

Some studies have found that refugee-specific factors play a role in understanding integration. Refugees with temporary legal status in the Netherlands have been shown to be more likely to be unemployed and to depend on social benefits than refugees who have already received Dutch nationality (Bakker et al., 2014). Another factor that can be viewed as closely related to legal status is the length of stay in a refugee reception centre. According to van Tubergen (2010), there is evidence of a negative relationship between the length of stay in a reception centre in the Netherlands and Dutch language proficiency. In the Netherlands, reception centres accommodate asylum seekers who wait for a decision on their refugee application. Hence, residents of reception centres can be viewed as a refugee group with a particularly precarious status. In both studies, refugees' legal status and specific factors that go along with legal status appear to translate into specific legal conditions that determine integration outcomes.

Another mechanism that determines differences in educational aspects of refugees is mental health. Several studies suggest that the mental health of refugees is influenced by factors related to the insecurity of their legal status (e.g., Heeren et al., 2016; Momartin et al., 2006). Mental health in turn can strongly influence educational outcomes (see, e.g., Basch, 2011; Dadaczynski, 2012). Mental health-related factors might also mediate the way an individual perceives his or her legal status. Despite these findings, we found no studies in which the effects of subjective status perception on educational outcomes has been studied.

\section{The Legal Framework of Refugee Schooling in Germany}

In Germany, all children of school age, i.e., children from the age of 6 to adolescents who are usually 18 years old, ${ }^{3}$ are required to attend school, and as Germany has ratified the United Nations Convention on the Rights of the Child, every child in Germany has the right to school access and education. Both compulsory schooling and the right to school access are independent of children's legal status. On a general level, refugees not only have legal access to schooling but are obliged to attend.

As educational legislative powers reside within German federal states, there are 16 different educational systems in Germany in which refugees' educational access is structured differently. In most federal states, primary education lasts for 4 years, after which students are historically assigned to three externally differentiated secondary school tracks with distinctive curricula: a lower secondary school track (Hauptschule) after which students continue to vocational training, a middle secondary school track (Realschule) leading to more advanced vocational training options, and an academic, higher secondary track (Gymnasium) for students who plan to undertake tertiary education. Today, in most federal states, there is a combination of the lower and middle secondary tracks (multitrack school) as a replacement for or as a complement to the two school types, and there is a comprehensive school that integrates all tracks in many federal states (von Maurice \& Roßbach, 2017). How refugees are distributed among the various forms of education and how their integration into schools is shaped varies significantly from one federal state to another (for a comprehensive overview of the legal situation of refugee schooling, see Massumi et al. 2015; for a focused view on the situation of the states the ReGES data were gathered in, see Will \& Homuth, 2020):

In general, compulsory schooling starts after immigrants have been assigned to a municipality or, as is the case in the city state of Hamburg, without delay after being assigned there. In Bavaria, schooling becomes compulsory 3 months after assignment to the federal state. However, most refugees are not assigned to a federal state and a municipality directly after arriving in Germany. They usually arrive in some form

2. The term "Aussiedler" denotes ethnic Germans who migrated from the Former Soviet Union and other Central and Eastern European states and received German citizenship through preferential provisions. The comparably immediate and nonbureaucratic naturalization procedure provided them with more beneficial conditions than migrants with other legal statuses in Germany (Bundesministerium des Innern, 2019).

3. There are differences between federal states that either prescribe mandatory schooling for a certain number of school years (usually 9 or 10 ) or until a certain age (18 or 21 ). 
of reception centre, where they apply for asylum and are sheltered until further allocation. Thus, many young refugees spend some time in Germany before they can attend school. ${ }^{4}$

The organizational integration of new immigrants into the school system is also handled differently in each federal state. The models range from schooling in separate classes for newcomers (complete external differentiation) to a partially integrated model (partial external differentiation) in which some subjects, such as physical education, are inclusively taught to full inclusion in regular classes (internal differentiation).

In the majority of schooling models, students are assigned to a school type and a grade level only when they transit from the newcomer class into a regular class. An exception to this rule is in Hamburg, where newcomer classes are already assigned to a certain school type, and in Bavaria, where a transition to a Gymnasium is provided only in exceptional cases. In allocation to a particular school track and a specific grade level, decision-makers are supposed to consider individual competencies, learning development, and predicted performance of the students. Since the transfer rules are flexible in most federal states, transition decisions are often left to the discretion of individual schools. Thus, it is unclear which mechanisms come to play at the transition moment, how strong the influence of teachers and parents is, and at what time this decision is made.

\section{Expected Effects of Legal Status: Theoretical Considerations and Hypotheses}

According to rational choice theory (hereafter RCT; see Breen \& Goldthorpe, 1997; Erikson \& Jonsson, 1996; Esser, 2006), educational attainment can be explained as the result of the sum of investment behaviour and educational decisions of calculating actors who try to maximize their educational outcomes within a given set of opportunities and restrictions. These actors hold different ideas and beliefs about certain options. Their perceptions influence their educational behaviour by altering the decision determinants, i.e., expected benefits, realization probabilities, and costs.

Several studies used RCT as a theoretical framework to conceptualize social integration, especially educational integration of migrants as the sum of constant small (e.g., active learning of the host country's language) and several big (e.g., choice of specific school tracks) investment decisions by students and their families (e.g., Esser, 2006; Jackson et al., 2012; Tjaden \& Scharenberg, 2017). To our knowledge, the RCT framework has not been utilized to explain the educational integration of refugees in particular (except for Will \& Homuth, 2020). We argue that refugees' integration into the educational system can be explained as well by RCT and understood as the result of a cost-benefit behaviour of students and their parents.

These investment decisions in education can be expected to be accompanied by anticipated benefits: education plays a central role in integrating young refugees into the host society. Furthermore, it is the central precondition for chances in later life. Even if the educational system in the host country prepares refugees especially for the needs of the host society, competencies acquired in the host country should also be valuable in the home country or other societies, to a certain extent.

Expected costs also influence the education investment decisions. While monetary costs should not play an important role in the German educational system, non-monetary costs may influence educational decisions: most notably, individuals may not know if it will be possible to finish their education. Insecurity could therefore decrease their willingness to invest in education.

In addition to refugee adolescents and their parents, another group of actors may be relevant in explaining educational outcomes: school staff influence the transition of refugee students from newcomer classes to regular classes and the type of school track to which a student is assigned. They decide when refugees have sufficient German skills and the necessary knowledge to cope with the learning requirements in regular classes. Ultimately, their decisions can also be modelled on the basis of considerations of costs and benefits: they might be incentivized to postpone transition for students with an insecure objective legal status, as it might harm the respective classes when students have to leave during the school year. For example, such a departure might have negative emotional effects on other (refugee) students or organizational effects when class sizes fall below certain thresholds that entitle schools to additional funding. In this

4. Refugees who do not have any prospect of staying in Germany, e.g., those who come from a state that has been defined as a safe country of origin, often remain in the reception facilities until their voluntary return or deportation. This means that they are seldom assigned to a municipality and thus, in some federal states, compulsory education does not begin. Nevertheless, all children and adolescents_-including those living in reception centres-have a right to attend school. There are, however, hardly any data available on the specific implementation of this right on the institutional side or claims for education by the refugees. Since, in particular, as a result of the nature of the sampling, refugees who have not been assigned to a municipality are not included in the ReGES sample, these aspects cannot be considered in more detail with the ReGES data. 
respect, teachers may try to avoid costs. Accordingly, we formulate the following hypothesis:

Hypothesis 1: Students with an insecure objective legal status are less likely to transition from newcomer classes to regular classes when controlling for known influential factors.

In contrast with the transition to a regular class, which we assume to be predominantly a decision by school personnel, we expect other educational decisions to be determined by factors on the individual level. The educational behaviour of refugees should vary if their objective legal status or their subjective status insecurity changes their evaluation of different educational options.

Therefore, we include two additional schooling aspects in our models: whether the students attended the higher secondary school track and the students' grade point averages (GPA). As Germany's educational system is very stratified and standardized (Allmendinger, 1989), educational chances and therefore long-term integration chances are highly dependent on the secondary school track. For this reason, first we look at the effect of legal status on secondary track or school placement. Second, we look at students' GPA in their current educational track, because GPA can be regarded as an indicator for the likelihood of graduating from the current track.

For these two outcomes, we derive the following hypotheses about the effect of legal status:

Hypothesis 2a: An insecure objective legal status has a negative impact on the attended track, as refugees with lower chances of staying see lower returns from education in Germany; they attend less-demanding and shorter school tracks.

Hypothesis $2 b$ : This effect is weaker for students from families with higher parental education, as these families value general/academic education more than less educated families do.

As perceived obstacles and not necessarily actual obstacles are the crucial aspect for (educational) decisions, we assume that subjective status insecurity might be the better measurement to capture the effects of legal status. Therefore, we include additional hypotheses using the independent variable subjective status insecurity.

Hypothesis $3 a$ : Subjective status insecurity has a negative impact on the attended track, as refugees with lower chances of staying incountry see lower returns from education in Germany.

Hypothesis $3 b$ : This effect is weaker for students from higher-educated families, as these families highly value education and would nevertheless invest in their children's education by pursuing more academic tracks.
We expect the effects of legal status on the performance of adolescents at school to be similar to the effects on school choice. In this regard, we assume that subjective status security is the more relevant factor, and formulate our hypotheses accordingly.

Hypothesis 4a: Students with subjective status insecurity show lower educational achievements due to a lower degree of motivation resulting from lower expected returns from educational investments, as they may not be able to stay in Germany.

Hypothesis $4 b$ : This effect is weaker for students with more educated parents as the result of a higher family value placed on education in general.

However, regarding the motivation to invest in destination-specific cultural and human capital (e.g., learning the language of the host country or obtaining a German school-leaving certificate), there could also be a contradictory expectation. In Germany, students without a permanent status can obtain an extension of residence status by attending certain educational courses. For example, the " $3+2$-Rule" ( $\$ 60 a$ Abs. 2 Sätze 4 und 5 AufenthG) allows asylum seekers with a declined application to stay during the time of their vocational training (normally lasting three years), as well as two additional years of work. Since information on this possibility is usually explained to refugees by other persons, the decisive aspect here is the refugees' objective legal status.

Hypothesis 4c: Students with an insecure objective legal status show higher educational achievements, as educational success is seen as a means to secure status extension in Germany. This effect should be independent of the parents' education.

In addition to the mechanisms already outlined, it can be stated that subjective status insecurity should influence achievement not only through motivation but also through its effect on mental health.

Hypothesis 5: Students who perceive subjective status insecurity should have worse (mental) health conditions, as they worry about their future and are not able to invest as much as students who feel rather secure about their status.

\section{Data and Methods}

Sample

Our dataset is drawn from the first panel wave of the ReGES longitudinal study, which includes data on the early integration of young refugees in Germany who came during the so-called refugee crisis. As part of the ReGES study, children 
and adolescents who lived with their parents in five federal states of Germany (Bavaria, Hamburg, North Rhine-Westphalia, Rhineland Palatinate, and Saxony) were accompanied for several years (for further information, see Homuth et al., 2020; Will et al., 2018). Our study focuses on a sample of 2,415 adolescents and their parents. At the time of the first interview in 2018, the adolescents were at the end of the lower secondary educational level and were set to transition shortly thereafter to higher secondary educational level or the vocational training system.

The analysis samples for the three outcomes were composed accordingly: For all analyses, we included only cases with completed parent interviews and generally excluded incomplete cases. ${ }^{5}$ For the analysis of school placement, we looked only at students who were already in regular classes, as we could expect their placement to be less volatile than for students who were still in newcomer classes. Furthermore, in practice, assignment to newcomer classes sometimes took place based on spatial availability and was not necessarily an indicator of the educational track students would be assigned to afterward. ${ }^{6}$ For analysis of GPA, we included only students who reported grades in the three domains of German, mathematics, and English.

\section{Outcomes}

The three outcome variables were operationalized and analyzed as follows:

1. Placement in newcomer vs. regular classes (reference category) as reported by the adolescents. The analysis sample contained 1,451 students.

2. Attended school type (educational track) as reported by the parents and recoded to Gymnasium (higher secondary school) vs. other secondary school types (reference category). The analysis sample contained 976 students.

For outcomes 1 and 2, we estimated linear probability models (LPM) with robust standard errors. LPM coefficients can be interpreted easily as changes of the probability in percentage points and are comparable with models with different covariates.

3. Educational achievement (GPA) as the average of the German, mathematics, and English grade points reported by the students. The analysis sample contained 1,144 students. We estimated multiple linear regression models with standard errors clustered on the class level.

\section{Explanatory Variables}

For legal status, we included two operationalizations:

1. Objective legal status represents the legal status of the students as reported by their parents. The German asylum procedure can lead to different outcomes that come along with varying rights. We classified objective legal status according to the regulations in force at the time of the study. Children who were granted refugee protection and those entitled to asylum received a residence permit for three years, with a possibility of long-term settlement after three or five years. These individuals were considered to be living under a "secure" status. In contrast, individuals staying in Germany under subsidiary protection, a ban on deportation, and those whose asylum claims were pending or had been rejected-and needed to leave Germany within one week or one month, depending on the kind of rejection (Bundesamt für Migration und Flüchtlinge, 2016) - were considered to be living with an "insecure" status.

2. Subjective status insecurity was measured with the question, "How likely do you think it is that you will be allowed to stay in Germany beyond your current temporary period of residency?" This question was answered based on a 4-point Likert scale. Because its distribution was skewed, the variable was recoded to "very likely" as the reference category, "likely," and "unlikely or very unlikely."

In our full models, we included explanatory variables that have been found to affect refugees' educational outcomes. These variables operationalize previous educational experiences, social inequality, migrant-specific factors, and refugee-specific factors (see Will \& Homuth, 2020).

To capture previous educational experiences, two variables were used: last attended school in the country of origin ("no school," "primary school," and "middle school or other school" as the reference), and students' self-rated educational achievements in the country of origin (scale: 0-100, centred on the country mean). We controlled for social background by including the highest occupational status the parents had in their home countries, highest parental education, and books at home in their countries of origin. For social status and parental education, missing indicators were included if parents did not report them. For migrant-specific aspects, we included students' self-reported German skills, the educational aspirations of the student receiving the school-leaving certificate (dichotomized as university entrance vs. other),

5. For some covariates, we include missing indicators in the models when exclusion would lead to biased results. This is indicated in the description of the covariates.

6. We also ran the analyses with the whole sample, including students in newcomer classes as sensitivity test. The results did not differ substantially. We show the results with the restricted sample only as it can be seen as the stricter test. 


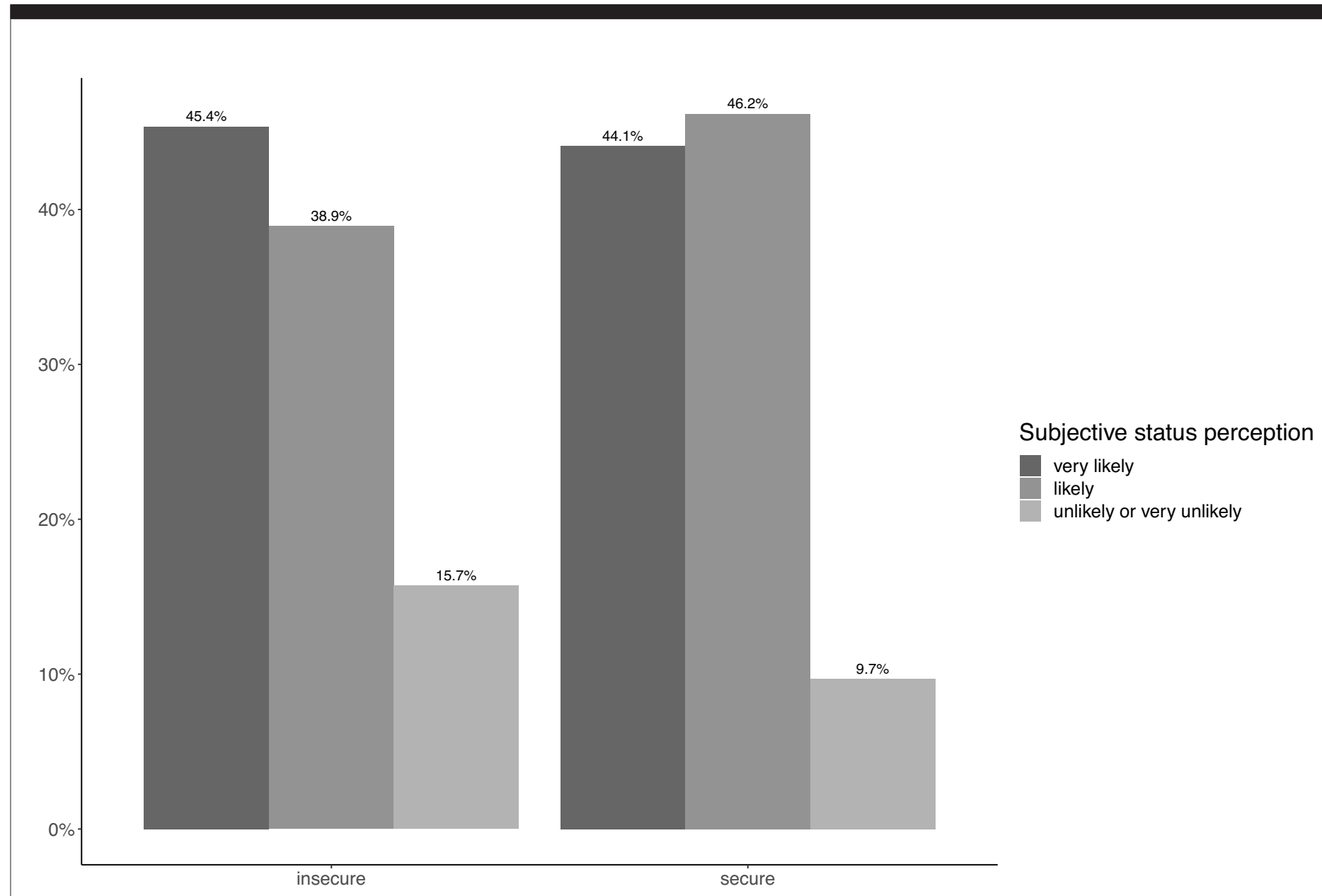

\section{Figure 1. Subjective Status Insecurity by Objective Legal Status}

Data: ReGES adolescent and parent interviews: wave 1.

Note: Secure (objective) legal status = refugee $/$ asylum status granted $(n=1,113)$; insecure (objective) legal status $=$ other status granted, decision pending or application rejected $(n=280)$. Differences in case numbers of the analysis sample result from item non-response on the subjective status insecurity variable.

and social contact with Germans ("daily," "several times a week," "weekly," "monthly," "never"). Refugee-specific factors included their return orientation to their countries of origin (yes vs. no), the duration of their journey to Germany (in months) as an indicator for time without schooling. Additionally, as an indicator for mental health, we use a post-traumatic stress disorder (PTSD) risk group indicator (dichotomous variable, "medium to high-risk vs. low-risk group," derived from a sum score of 10 PTSD symptoms).

Further control variables cover the federal state, gender, student age in months, and country of origin (Afghanistan, Iraq, Syria, and Others).

In the analysis of the attended class type (newcomer vs. regular class), we included the period of residence in Germany (in months) and the wait period in Germany (in months) before they attended school. In the analysis of GPA, we include the currently attended school type (Hauptschule, Realschule, Gymnasium, comprehensive school, multitrack school).

\section{Results \\ Descriptive Findings}

The following section provides a descriptive overview of our central variables. While the frequency distributions of the dependent variables are based on the respective analysis samples, univariate and bivariate analyses of our central independent variables refer to the first analysis sample (placement in newcomer vs. regular classes) because it is the largest sample $(1,451) .^{7}$ Most adolescents had a secure

7. We checked the frequency distributions of our central independent variables in all three analysis samples and found no substantive differences between the respective distributions. Only for the bivariate analysis of objective legal status and subjective 


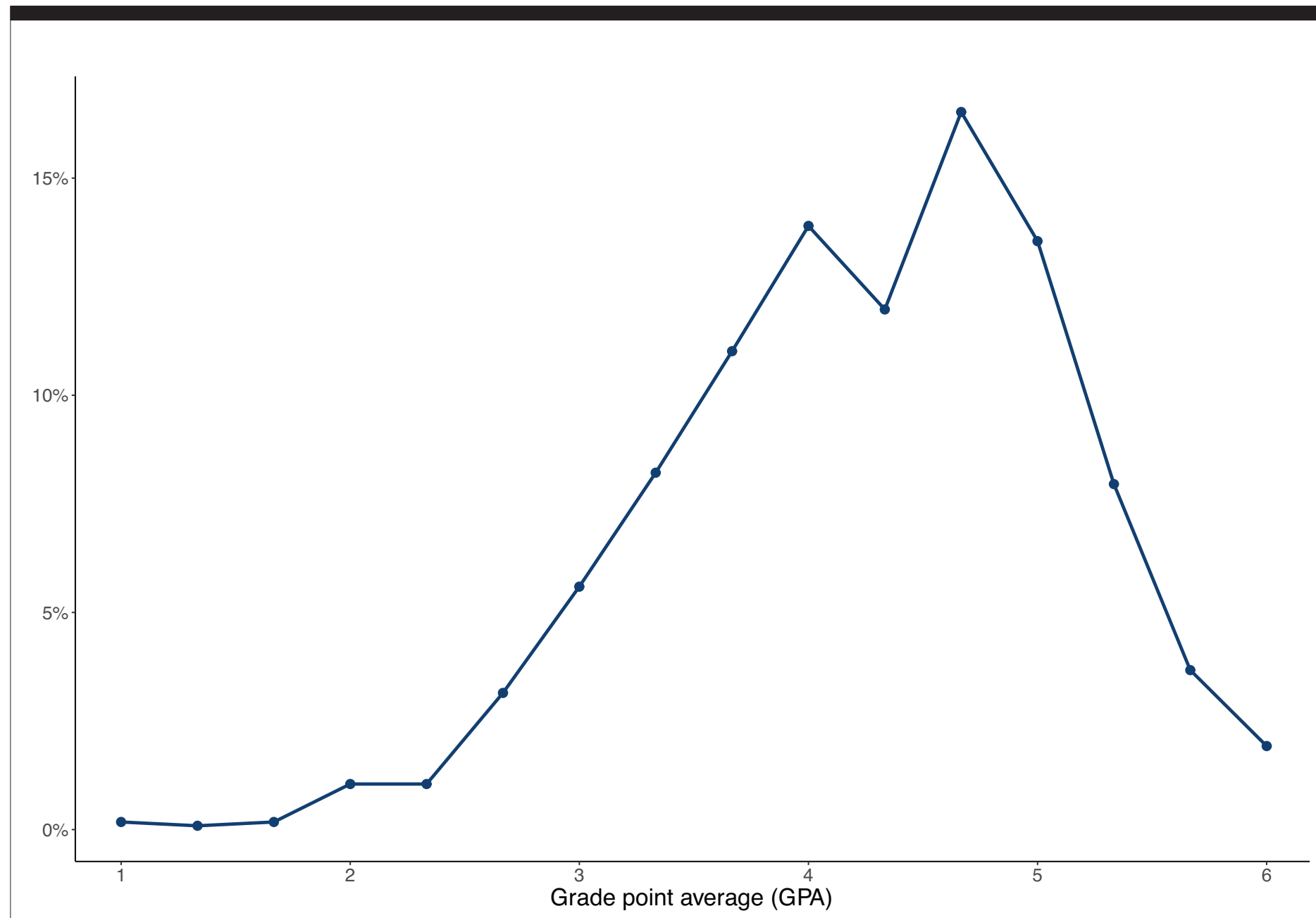

Figure 2. Distribution of GPA ( $1=$ insufficient; $6=$ very good)

Data: ReGES adolescent interview; wave 1; $n=1,144$.

objective legal status: $79.5 \%$ had been recognized as refugees. Only a minority of $20.5 \%$ of respondents had an insecure objective legal status-that is, they received only subsidiary protection, or their application was still pending or had been declined.

Looking at the adolescents' subjective status insecurity, we observe that an overwhelming majority perceived their prospect of staying in Germany as very likely (44.4\%) or likely (44.7\%), whereas only $10.9 \%$ of the respondents estimated that their chances to stay were unlikely or very unlikely. Surprisingly, differences in subjective status insecurity were not very pronounced between those with a secure legal status and those with an insecure legal status (see Figure 1).
Turning to our outcome variables, we found that our first analysis sample for the placement in newcomer vs. regular classes consisted of approximately two-thirds of adolescents who were attending regular classes (65.3\%) and one-third who had been assigned to newcomer classes. The attended educational track, which is the relevant dependent variable in our second analysis sample, was Gymnasium in less than a fifth of cases (17.9\%), with the rest of the sub-sample attending other secondary school types (82.1\%). Third, the ReGES adolescents reported an average GPA of $4.3(S D=0.86$; see Figure 2). ${ }^{8}$

status insecurity were there significant deviations in the school track sample $(n=976)$ : Among adolescents with an insecure objective legal status, a lower proportion (40.2\% compared to $45.3 \%)$ rated their prospect of staying as very likely, and more ( $45.3 \%$ vs. $38.9 \%)$ rate this as likely.

8. The German grading scale is: $1=$ very good, $2=$ good, $3=$ satisfactory, $4=$ sufficient, $5=$ poor, and $6=$ insufficient. We recoded the GPA to $1=$ insufficient to $6=$ very good, for easier interpretation. 


\section{Table 1. Impact of Legal Status on Class Type}

\begin{tabular}{|c|c|c|}
\hline $\begin{array}{l}\text { Outcome 1: } \\
\text { Placement in newcomer vs. regular classes (reference category) }\end{array}$ & $\begin{array}{l}\text { Model } 1.1 \\
\text { Only objective status }\end{array}$ & $\begin{array}{l}\text { Model } 1.2 \\
\text { Objective status + all } \\
\text { covariates }\end{array}$ \\
\hline Parental education (HISCED level) & & $\begin{array}{l}-0.012 \\
(0.013)\end{array}$ \\
\hline
\end{tabular}

Data: ReGES adolescent and parent interview: wave $1 ; n=1,451$. Notes: Unstandardized linear regression coefficients. Robust standard errors in parentheses. Controlled for covariates listed in section 5.3. $+p<0.1{ }^{*} p<0.05^{* *} p<0.01$.

\section{Multivariate Findings}

Table 1 shows the results for the analysis of the impact of legal status on class type. Students who had an insecure objective status were more likely to attend a newcomer class (cf. Model 1.1). However, this difference was not significant.

When controlling for possible confounders, including residence duration in Germany, the difference became even smaller (cf. Model 1.2). Therefore, we reject hypothesis 1, that an insecure status leads schools to delay the transition into regular classes.

Table 2 shows the results for the second outcome of interest, the placement of refugee students in the academic secondary school track. The first two models (cf., Models $2.1,2.2$ ) indicate that there was neither a difference in track placement between students with objectively secure or insecure legal status nor a difference in students' subjective status insecurity. Even when controlling for possible confounders and important mechanisms to explain academic track placement (e.g., parental education, previous educational experiences), there was no evidence of an impact of legal status (cf., Model 2.3, 2.4). Thus, hypotheses $2 \mathrm{a}$ and $3 \mathrm{a}$ can be rejected. As shown in Models 2.5 and 2.6, we see, in line with our hypotheses, minor differences in the effect of objective legal status and subjective status insecurity for students from different educational backgrounds. However, these differences were not significant, so we reject hypotheses $2 \mathrm{~b}$ and $3 \mathrm{~b}$ as well.

Finally, Table 3 shows the results for the impact of legal status on students' GPA. Model 3.2 shows that students with high subjective status insecurity reported significantly worse GPA, compared with students who feel rather secure. This outcome corroborates hypothesis $4 \mathrm{a}$. In contrast, we found that students with an insecure objective legal status reported significantly better GPA than students with a secure legal status (cf. Model 3.1). This finding corroborates hypothesis $4 \mathrm{c}$, that students are more motivated to perform well in school as a means to perhaps receive a better objective legal status in the future.

When we controlled for objective legal status and subjective status insecurity, we saw an increase in their respective coefficients (cf. Model 3.3). This observation affirms the descriptive finding that there were indeed students whose perceptions about their subjective status insecurity did not match their objective legal status.

In Models 3.5a, 3.5b, and 3.6, we controlled for possible confounders. While the effect for the objective legal status remained constant, we can partly explain the effect of the subjective status insecurity by including the covariates into our models. However, the decline in effect size and level of significance was not due to our measurement of mental health. In a model in which only the PTSD risk was controlled in addition to subjective status insecurity (cf. Model 3.4), the observed effect of subjective status insecurity changed only marginally. Therefore, we have to reject hypothesis 5 .

In Models 3.7 and 3.8, hypotheses about assumed differences by educational background were tested ( $4 \mathrm{~b}$ and $4 \mathrm{c}$ ). Neither hypothesis was corroborated: Students with higher subjective status insecurity reported worse grades; however, this effect existed regardless of the education of their parents. Concerning the effect of objective legal status, parental education was unexpectedly important: students with highereducated parents reported better GPAs, and students with an insecure objective status reported better GPAs. However, the effect of an insecure legal status was less important for students with higher-educated parents than for students with lower-educated parents. We can understand this outcome as meaning that the motivational boost is not as large because students with higher-educated parents are already very motivated in school. 
Table 2. Impact of Objective Status and Subjective Insecurity on Educational Track

\begin{tabular}{|c|c|c|c|c|c|c|}
\hline \multicolumn{7}{|l|}{$\begin{array}{l}\text { Outcome 2: } \\
\text { Educational }\end{array}$} \\
\hline Track (Academic & & & Model 2.3 & & Model 2.5 & Model 2.6 \\
\hline $\begin{array}{l}\text { vs. other); other } \\
\text { = reference } \\
\text { category }\end{array}$ & $\begin{array}{c}\text { Model } 2.1 \\
\text { Objective } \\
\text { status } \\
\end{array}$ & $\begin{array}{c}\text { Model } 2.2 \\
\text { Subjective } \\
\text { status } \\
\end{array}$ & $\begin{array}{c}\text { Obj. status } \\
+ \text { all covariates }\end{array}$ & $\begin{array}{c}\text { Model } \mathbf{2 . 4} \\
\text { Subj. status } \\
+ \text { all covariates }\end{array}$ & $\begin{array}{c}\text { Obj. status } \\
+ \text { all covariates } \\
\text { +interaction }\end{array}$ & $\begin{array}{c}\text { Subj. status } \\
+ \text { all covariates } \\
+ \text { interaction }\end{array}$ \\
\hline Insecure objective & 0.000 & & 0.014 & & 0.023 & \\
\hline Subjective status & & -0.015 & & 0.019 & & 0.048 \\
\hline insecurity & & (0.019) & & (0.019) & & $(0.030)$ \\
\hline Parental education & & & $0.030^{*}$ & $0.030^{*}$ & $0.031^{*}$ & $0.040^{*}$ \\
\hline (HISCED level) & & & $(0.015)$ & (0.015) & (0.015) & $(0.018)$ \\
\hline$R^{2}$ & 0.000 & 0.001 & 0.072 & 0.073 & 0.073 & 0.075 \\
\hline
\end{tabular}

Data: ReGES adolescent and parent interview: wave $1 ; n=976$.

Notes: Unstandardized linear regression coefficients. Robust standard errors in parentheses. Controlled for covariates listed in section 5.3. $+p<0.1 * p<0.05^{* *} p<0.01$.

\section{Summary and Conclusion}

Under German law, all children must attend school at a given age and at the latest when they are assigned to a municipality-independent of their legal status. Compared to other jurisdictions, the German education system provides a solid basis for educational equity (UNESCO, 2018). In this article, based on a series of research hypotheses, we analyzed in detail the effect of refugee students' legal status in Germany. Our dataset included adolescents who had already been assigned to a municipality, and our analysis focused on different schooling aspects: class type, educational track, and grades.

First, our analyses showed the results of the different school allocation policies for refugee students in the federal states under study: we found no significant differences among students with different objective legal statuses in placement in a newcomer or a regular class and for the attended school type (academic vs. non-academic). This politically important outcome means that the politically set aims for educational equity of students with different legal statuses are not counteracted in the practical implementation-by targeted actions or by the unconscious processes of the decision-makers involved. Further research is needed to assess whether objective legal status is also irrelevant for the following educational trajectories, including vocational training, as well as upper secondary and tertiary education.
Second, to better understand what happens within schools, we focused on educational achievement and found differences in the reported grades of students, depending on their objective legal status: students with an insecure objective legal status reported better grades than those with a secure legal status. This outcome could be due to a higher motivation to perform better in school. An alternative explanation could be that these students reported higher GPAs to give a more socially desirable answer. However, this cannot be determined only by looking at student self-reports. A further avenue of analysis would be to examine the reports from teachers, who were also part of the ReGES study, to validate the students' answers and find more evidence on the mechanism driving these results.

Third, we analyzed whether objective legal status is associated with the subjective status insecurity of refugee adolescents. Surprisingly, only $15.7 \%$ of adolescents with a more insecure objective legal status saw their chances to stay in Germany as unlikely or very unlikely. This outcome demonstrates the weak overlap between objective legal status and subjective status insecurity among adolescent refugees. These results warrant further study of the determinants of subjective status insecurity, as well as analyses of whether objective legal status and subjective status insecurity converge over time. This discrepancy, and especially the effects of subjective status insecurity on educational parameters, 
Table 3. Impact of Objective Status and Subjective Insecurity on GPA

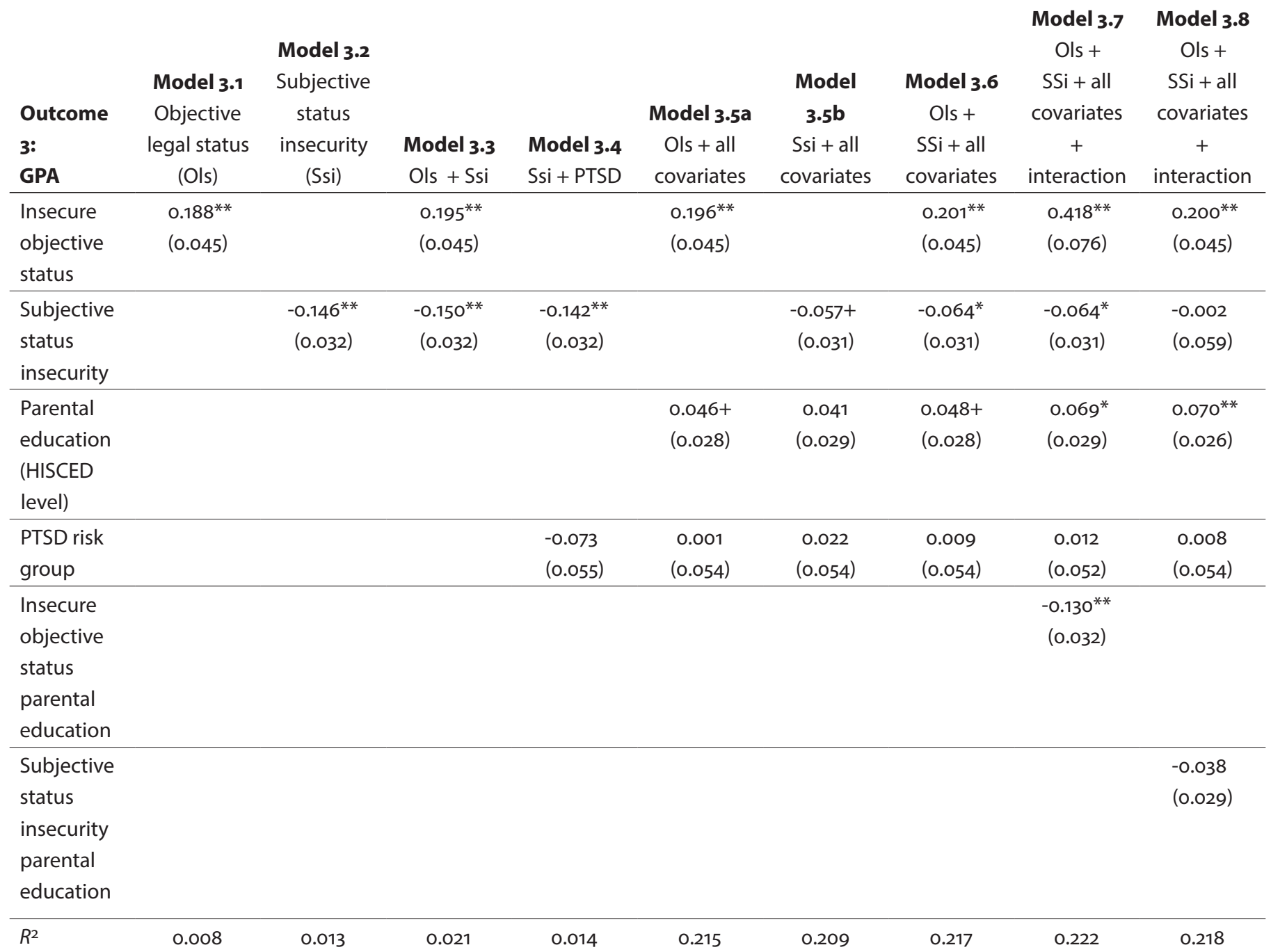

Data: ReGES adolescent and parent interview: wave $1 ; n=1,144$.

Notes: Unstandardized linear regression coefficients. Standard errors are clustered on the class level, in parentheses. Controlled for covariates listed in section 5.3. $+p<0.1 * p<0.05 * * 0.01$.

are of utmost practical and theoretical importance and are still not comprehensively addressed in the literature.

Fourth, we found that students with higher subjective status insecurity reported worse grades, while students with an insecure objective legal status reported better grades. This aspect is very important and has not been explored in previous studies. Further research has to account for both constructs, which are necessary to understand the educational success of refugees, as one cannot be explained or approximated by the other.

Fifth, among the refugees within our sample, we found inequalities of educational opportunities based on social origin. Refugee students with higher-educated parents generally did better in school than those with lower-educated parents.
In addition, adolescents from more advantaged backgrounds were less affected by an insecure objective legal status than students from disadvantaged backgrounds. Taken together with the effects shown regarding subjective status insecurity, this outcome deepens the theoretical understanding and the empirical basis of the heterogeneity within the large group of adolescent refugees in Germany.

Based on a joint consideration of these results, there are some more general implications for refugee research as well as for (school) practice.

The results show that the concentration on objective security parameters is not sufficient in a research-based understanding of the situation of refugees. Although we saw a weak correlation between objective legal status and 
subjective status insecurity in adolescent refugees, we also saw that even adolescents who have a comparatively secure objective legal status can experience subjective status insecurity. This feeling of insecurity could have an impact not only on educational trajectories but also on a variety of life domains, such as family dynamics, peer relationships, and mental health. Furthermore, an insecure legal status could be connected to subjective security in a way that it could work as a buffer against aversive constellations. Subjective insecurity is considered only partially in forced-migration research, and especially the combined consideration of indicators for objective and subjective security has been lacking. Theoretical considerations, as well as process-relevant information, might be derived from extended literature on the difference and differential effects of subjective and objective employment insecurity (e.g., Helbling \& Kanji, 2018; Hipp, 2020). First and foremost, our results are not at all-from a research-based point of view-sufficient for understanding educational trajectories, as they are limited to a single measurement; forced-migration studies instead need to adopt longitudinal designs. Concerning school allocation, mid- and long-term effects of insecurity on upper secondary and tertiary education as well as on vocational training have to be considered.

The increasing population of refugees in Germany poses new challenges to school administration, teachers, school psychologists, educational counsellors, and classroom assistants. These expert practitioners should be aware of the potential divergence between objective and subjective security parameters and their corresponding effects on educational trajectories. This is especially important as objective security parameters are often obvious, whereas subjective insecurity might be much harder to explore. The issue of refugees' insecurity should be naturally considered in everyday educational practice within the school context, but further explicit interventions might be necessary, nonetheless. In a systematic review of school-based social-emotional interventions, Sullivan and Simonson (2016) differentiate between interventions based on cognitive behavioural therapy, creative expression, and mixed methods (see also the meta-analysis by Tyrer \& Fazel, 2014). But the need for dealing with an insecure objective legal status and subjective status insecurity-along with other refugee-specific aspects, usually manifest in a different cultural background, poor language skills, and traumatic experiences in some cases-should have implications for the training of all practitioner groups involved-most importantly in teacher training. These needs should be recognized and addressed by policy and school administration. Even though Sullivan and Simonson (2016) clearly point out "schools as a key site for services to refugees" (p. 508), the above-mentioned aspects are also relevant outside of school, especially for community workers and health-care experts.

Finally, there are limitations on the generalization of our results. Primarily, the results shown are limited to the sample under study, with participants being recruited within five federal states in Germany. It can cautiously be argued that these results might be generalized to all German federal states. But it remains an open question whether our results can be generalized to other countries or cultural contexts. In this regard, however, refugees applying for asylum in Germany may differ from those staying in the vicinity of their countries of origin (e.g., Syrian refugees in Germany vs. Syrian refugees in Lebanon) concerning their subjective status insecurity, social background, and educational developments (see Spörlein et al., 2020). However, even within Germany, there are some restrictions: nationals from "safe countries" do not receive asylum and therefore cannot seek protection in Germany. As these people are seldom assigned to a municipality, they infrequently have the chance to visit regular schools, and children often do not attend regular German schools. However, as the state is obligated to educate all school-aged children, these children generally receive special treatment in refugee reception centres. These children were not included in the ReGES study by design. Moreover, the group of unaccompanied minors-which are taken care of in a quite different manner in Germany and likely have different perceptions about subjective status insecurity-was also excluded by design. Therefore, the presented results are not generalizable to these specific groups.

\section{Acknowledgments}

The ReGES project on which this article is partly based is funded by the German Federal Ministry of Education and Research under grant number FLUCHTO3. The content of this publication is solely the responsibility of the authors.

\section{References}

Allmendinger, J. (1989). Educational systems and labor market outcomes. European Sociological Review, 5(3), 231250. https://doi.org/10.1093/oxfordjournals.esr.a036524

Bakker, L., Dagevos, J., \& Engbersen, G. (2014). The importance of resources and security in the socio-economic integration of refugees: A study on the impact of length of stay in asylum accommodation and residence status on socio-economic integration for the four largest refugee groups in the Netherlands. Journal of International Migration and Integration, 15(3), 431-448. https://doi. org/10.1007/s12134-013-0296-2

Basch, C. E. (2011). Healthier students are better learners: A missing link in school reforms to close the achievement 
gap. Journal of School Health, 81(10), 593-598. https://doi. org/10.1111/j.1746-1561.2011.00632.x

Breen, R., \& Goldthorpe, J. H. (1997). Explaining educational differentials: Towards a Formal Rational Action Theory. Rationality and Society, 9(3), 275-305. https:// doi.org/10.1177/104346397009003002

Bundesamt für Migration und Flüchtlinge (вАмғ). (2016). The stages of the German asylum procedure: An overview of the individual procedural steps and the legal basis. Nurenberg: BAMF.

Bundesamt für Migration und Flüchtlinge (вАмF). (2018). Das Bundesamt in Zahlen 2017. Asyl, Migration und Integration [The federal office in numbers 2017: Asylum, migration and integration]. Nurenberg: BAMF.

Dadaczynski, K. (2012). Stand der Forschung zum Zusammenhang von Gesundheit und Bildung [State of research on the relationship between health and education]. Zeitschrift für Gesundheitspsychologie, 20(3), 141-153. https:// doi.org/10.1026/0943-8149/aoooo72

de Paiva Lareiro, C. (2019). Ankommen im deutschen Bildungssystem. Bildungsbeteiligung von geflüchteten Kindern und Jugendlichen [Arrival in the German education system: Educational participation of refugee children and adolescents]. Nurenberg: Bundesamt für Migration und Flüchtlinge.

Erikson, R., \& Jonsson, J. (1996). Explaining class inequality in education: The Swedish test case. In R. Erikson \& J. Jonsson (Eds.), Can education be equalized? The Swedish case in comparative perspective (pp. 1-63). Boulder, co: Westview Press.

Esser, H. (2006). Sprache und Integration: Die sozialen Bedingungen und Folgen des Spracherwerbs von Migranten [Language and integration: the social conditions and consequences of language acquisition among migrants]. Frankfurt a.M.: Campus.

Greenman, E., \& Hall, M. (2013). Legal status and educational transitions for Mexican and Central American immigrant youth. Social Forces, 91(4), 1475-1498. https:// doi.org/10.1093/sf/soto4o

Heeren, M., Wittmann, L., Ehlert, U., Schnyder, U., Maier, T., \& Müller, J. (2016). Psychopathologie und Aufenthaltsstatus [Psychopathology and residence status]. Forum der Psychoanalyse, 32(2), 135-149. https://doi. org/10.1007/s00451-016-0235-X

Helbling, L., \& Kanji, S. (2018). Job insecurity: Differential effects of subjective and objective measures on life satisfaction trajectories of workers aged 27-30 in Germany. Social Indicators Research, 137, 1145-1116. https://doi. org/10.1007/s11205-017-1635-Z

Hipp, L. (2020). Feeling secure vs. being secure? Qualitative evidence on the relationship between labour market institutions and employees' perceived job security from Germany and the U.S. Contemporary Social Science, 15(4), 416-429. https://doi.org/10.1080/21582041.2019.16 56816

Homuth, C., Will, G., \& von Maurice, J. (2020). Broken school biographies of adolescent refugees in Germany. In A. Korntheuer, D. Maehler, P. Pritchard, \& L. Wilkinson (Eds.), Refugees in Canada and Germany: Responses in policy and practice (pp. 123-142). Cologne: GESIsLeibniz-Institut für Sozialwissenschaften.

Jackson, M., Jonsson, J. O., \& Rudolphi, F. (2012). Ethnic inequality in choice-driven education systems: A longitudinal study of performance and choice in England and Sweden. Sociology of Education, 85(2), 158-178. https:// doi.org/10.1177/0038040711427311

Lee, R. (2018). Immigrant entry visa categories and their effects on the children of immigrants' education. Journal of Ethnic and Migration Studies, 44(9), 1560-1583. https:// doi.org/10.1080/1369183X.2017.1362976

Massumi, M., von Dewitz, N., Grießbach, J., Terhart, H., Wagner, K., Hippmann, K., \& Altinay, L. (2015). Neu zugewanderte Kinder und Jugendliche im deutschen Schulsystem [Newly immigrated children and adolescents in the German school system]. Cologne: Mercator-Institut für Sprachförderung und Deutsch als Zweitsprache.

Momartin, S., Steel, Z., Coello, M., Aroche, J., Silove, D. M., \& Brooks, R. (2006). A comparison of the mental health of refugees with temporary versus permanent protection visas. Medical Journal of Australia, 185(7), 357-361. https://doi.org/10.5694/j.1326-5377.2006.tboo610.x

Morris, L. (2003). Managing contradiction: Civic stratification and migrants' rights. International Migration Review, 37(1), 74-100. https://doi.org/10.1111/j.1747-7379.2003. tboo130.x.

Nationaler Aktionsplan Integration (2012). Zusammenhalt stärken-Teilhabe verwirklichen [Strengthening cohesion: Making participation a reality]. Berlin: Die Beauftragte der Bundesregierung für Migration, Flüchtlinge und Integration.

OECD. (2020).Educationataglance 2020: OECD indicators. Paris: OECD Publishing. https://doi.org/10.1787/69096873-en

Oltmer, J. (2016). Die globale Flüchtlingsfrage und Deutschland [The global refugee question and Germany]. DJI impulse. Das Bulletin des Deutschen Jugendinstituts, 3, 28-32.

Patler, C. (2018). Citizen advantage, undocumented disadvantage, or both? The comparative educational outcomes of second and 1.5-generation Latino young adults. International Migration Review, 52(4), 1080-1110. https:// doi.org/10.1111/imre.12347 
Söhn, J. (2011). Rechtsstatus und Bildungschancen die staatliche Ungleichbehandlung von Migrantengruppen und ihre Konsequenzen [Legal status and educational opportunities, the unequal treatment of migrant groups by the state and its consequences.]. Wiesbaden: VS Verlag für Sozialwissenschaften. https://doi. org/10.1007/978-3-531-93364-1

Söhn, J. (2014). How legal status contributes to differential integration opportunities. Migration Studies, 2(3), 369391. https://doi.org/10.1093/migration/mnuo22

Spörlein, C., Kristen, C., Schmidt, R., \& Welker, J. (2020). Selectivity profiles of recently arrived refugees and labour migrants in Germany. Soziale Welt, 71(1-2), 54-89. https://doi.org/10.5771/0038-6073-2020-1-2-54

Sullivan, A. L., \& Simonson, G. R. (2016). A systematic review of school-based social-emotional interventions for refugee and war-traumatized youth. Review of Educational Research, 86(2), 503-530. https://doi. org/10.3102/0034654315609419

Tjaden, J. D., \& Scharenberg, K. (2017). Ethnic choice effects at the transition into upper-secondary education in Switzerland. Acta Sociologica, 6o(4), 309-324. https:// doi.org/10.1177/0oo1699316679491

Tyrer, R. A., \& Fazel, M. (2014). School and communitybased interventions for refugee and asylum seeking children: A systematic review (corrected article). PLOS ONE, 9(2), 1-12. https://doi.org/10.1371/journal.pone.0089359

UNESCO. (2018). Global education monitoring report 2019: Migration, displacement and education-building bridges, not walls. Paris: UNESCO.

United Nations High Commissioner for Refugees (UNHCR). (2019). Global trends: Forced displacement 2018. Geneva: UNHCR.

van Tubergen, F. (2010). Determinants of second language proficiency among refugees in the Netherlands. Social Forces, 89(2), 515-534. https://doi.org/10.1353/ sof.2010.0092 von Maurice, J., \& Roßbach, H.-G. (2017). The educational system in Germany. In A. Korntheuer, D. B. Maehler, \& P. Pritchard (Eds.), Structural context of refugee integration in Canada and Germany (pp. 49-52). Cologne: GEsisLeibniz-Institut für Sozialwissenschaften. https://doi. org/10.21241/ssoar.52101

Will, G., Gentile, R., Heinritz, F., \& von Maurice, J. (2018). ReGES-Refugees in the German Educational SystemÜberblick über Forschungsdesign, Stichprobenziehung und Ausschöpfung der ersten Welle [ReGES-Refugees in the German Educational System-Overview of research design, sampling and sample coverage of the first wave]. Bamberg: Leibniz-Institut für Bildungsverläufe.

Will, G., \& Homuth, C. (2020). Education of refugee adolescents at the end of secondary school: The role of educational policies, individual and familial resources. Soziale Welt, 71(1-2), 161-201. https://doi. org/10.5771/0038-6073-2020-1-2-160

Christoph Homuth is head of the working unit "Educational Decisions and Social Inequality," Leibniz Institute for Educational Trajectories, Germany. He can be reached at christoph. homuth@lifbi.de.

Jörg Welker is a research assistant in the "Refugees in the German Educational System" project, Leibniz Institute for Educational Trajectories, Germany. He can be reached at joerg. welker@lifbi.de.

Gisela Will is head of the working unit "Migration," Leibniz Institute for Educational Trajectories, Germany. She can be reached at gisela.will@lifbi.de.

Jutta von Maurice is head of the Centre for Study Management, Leibniz Institute for Educational Trajectories, Germany. She can be reached at jutta.von-maurice@lifbi.de. 